\title{
DEVELOPMENT PROSPECTS OF INCENTIVE TAXATION MECHANISMS OF BUSINESS ENTITIES IN AGRICULTURAL SECTOR OF THE ECONOMY
}

\author{
O. O. NEPOCHATENKO, Doctor of Economic Sciences, Professor \\ P. K. BECHKO, $P h D$ in Economics, Professor \\ S. A. VLASIUK, PhD in Economics, Associate Professor \\ O. V. PONOMARENKO, teacher \\ J. I. NAGORNA, post-graduate \\ Uman National University of Horticulture
}

У статі сформовано $і$ систематизовано авторський підхід щодо перспектив розвитку механізмів податкового стимулювання суб'єктів господарювання аграрного сектору економіки. Запропоновано на законодавчому рівні запровадити зміни до Податкового кодексу України щяодо оподаткування аграріїв єдиним податком (четверта група), в залежності від їх спеціалізації, надавщи преферениії сільськогосподарським товаровиробникам з виробництва тваринницької продукиї та її переробки.

Ключові слова: єдиний податок(четверта) група, спеціалізація виробництва, Податковий кодекс України, рівень рентабельності, мінімізація податкових зобов 'язань, спрощена система оподаткування.

Problem statement. In the contemporary world, an agricultural sector of the national economy is facing a system call, which essence is to update the material and technical, technological, scientific and information involving general bestmanagement practices and technologies. The priority assignment for agricultural sector is the necessity to raise its development to a qualitatively new level with the support of state financing. A specific mechanism for improving the state financial support of farmers is fiscal incentives based on a differentiated approach depending on the exact amounts of direct state financial support received by each business entity. In the meantime, insufficient attention is being devoted to the problem of fiscal incentives of agricultural entities that significantly affects their increased reproduction, creating an imbalance in its internal development, disturbance of agricultural production technology.

Removing special regimes of taxation through the introduction of a value-added tax, increasing in the tax base and single rate of income tax (the fourth group) led to the increase of tax burden and had negative impact on agricultural organizations of different forms of management. The overwhelming majority of them do not comply with progressive technologies of growing crops, crop rotation of production. Animal production made by agricultural enterprises is declining, which leads to an increase in 
importation of such products, while the native agricultural industry has a capacity of increasing its own production for local and international marketing.

The review of recent research and publications. The contemporary nature of development mechanism for incentive taxation of economic entities in agricultural sector of the economy is under constant review of both theorists and practitioners who study the taxation problems of farmers. Meanwhile, at the legislative level, laws are being adopted that have negative impact on the results of financial operation of economic entities in the agricultural industry and lead to an increasing in tax pressure on the whole industry. Tax incentives for farmers have the potential increase the efficiency of their operation on self-funded and self-sufficiency. Among scientists working on the problems of development prospects of incentive taxation mechanisms of business entities in agrarian sector, it is appropriate to distinguish the successes of such scientists as A. Antipov [1], P. Bechko [2], V. Bychkov [3], S. Brekhov [4], O. Vilkova [5], V. Prigotsky [6], K. Proskura [7], Sidorenko R.V. [8] and many others. At the same time, solutions to this issue for national farmers in current situation have not yet been completely researched, they require further study, using both foreign and native experience in order to implement it in national tax system.

The purpose of the research is theoretical foundation of the prospects for the development of tax incentives mechanisms of business entities in agricultural sector of the economy attracting the advanced methodological tools developed by both international and native tax system experience.

Research methodology. The methodological background of the study is economic theory, scientific developments of international and native scientists on the development of tax incentives mechanisms for economic entities in the agricultural sector of the economy. During the research, the following techniques were applied: abstract logical, method of comparison, monographic and scientific synthesis.

Research results. The review of theoretical foundation, legislation in the area of fiscal charges of business entities in agricultural sector of the economy as well as an assessment of the level, trends and rate of the tax burden in agriculture point to the need for adaptation the current tax system to current challenges. Despite the fact that agriculture has a large number of benefits and preferences, the tax system does not still completely pursue its facilitating role. The fiscal policy, prevailing in the native tax system due to its complexity and ambivalent, impedes the implementation of certain tax benefits by business entities in the agricultural sector, which significantly affects the process of stabilization and development of the industry in the context of expanded reproduction, self-funding and self-sufficiency.

Considering this fact, "the authorities have not yet managed to create effective business entities, such as cooperatives for sustainable rural development. The condition of modern rural areas is characterized by a lack of workplaces and social infrastructure, which leads to a demographic crisis and the extinction of villages, social tension, a decrease in the demographic reproductive base and the loss of the ethnographic heritage of Ukraine" [9]. Over recent years, a significant change has taken place in the taxation of agricultural producers. In particular, the special regime of taxation with value added tax has been canceled; the rates and the taxable base by 
the single tax (fourth) group have been significantly increased. At the same time, onetime types of subsidies have been introduced for agricultural producers. However, the application exclusively subsidies as a means of tax incentives for business entities in the agricultural sector cannot provide high-quality, diverse and targeted support. Taking this into account, it is important to reformat the tax system in terms of both their taxation and tax incentives. Considering that fact, it is necessary to reform the tax system in terms of both their taxation and tax incentives.

By November 1, 2020, in Ukraine, the number of agricultural enterprises and farms, depending on the amount of land, was (table 1). According to the above indicators, among the entities of the agricultural sector, the largest part is occupied by those who own more than 100,000 hectares. Their amount is 184 economic entities or $21.1 \%$ of the total. What is specific that $66.2 \%$ owned land that did not exceed 1000 hectares per enterprise. A similar state of affairs among farms, 24438 of which or $76.7 \%$ owned plots, the size of which did not exceed 500 hectares per farm.

Taking into account that all agricultural manufacturers are compartmentalized there is a concern about their investment, lending and ways of marketing that makes it impossible to deal with self-funding and self-suffiency. Management of the crisis in the industry is possible with the simultaneous improvement of the single tax (fourth) group, lowering the tax burden, expanding tax preferences for entities investing in agriculture. Meanwhile, it should be pointed out that in world practice; in particular, in countries with developed market relations, there is no analogue of a single tax for agriculture. There is a sinfle tax in some countries, but only for small farms. Preferential tax treatment applies in Russia and Belarus. In particular, in Belarus, a preferential tax treatment is provided for farmers for three years, and in Russia, the incentive is provided for five years after the creation of business entities - farmers. In Ukraine, a simplified taxation system has been introduced for agricultural enterprises, based on the providing a single tax (fourth) group. By November 1, 2011, the single tax rate per hectare of agricultural land and water fund lands depends on the category (type) of land, their location and is (in \% of the taxable base of Art. 292-1.2 of the Tax Code.

Contributors to the single tax (fourth group) can be agricultural producers legal entities, regardless of the organizational and legal form, in which the share of agricultural production for the previous tax (reporting) year is equal to or exceeds $75 \%$.

Furthermore, the contributors to the single tax (fourth) group can be individual entrepreneurs who function exclusively within the farm, provided that the following set of requirements are met: grow exclusively agricultural products, fattening of livestock, processing of actually grown or fattened products and their sale; provide economic activities (except supplying ) at the tax address; do not use employees; members of such an individual farms are only members of their family; the area of agricultural land or water fund owned or used by members of the farm is at least two hectares, but not more than 20 hectares [10]. 
Table 1. Division of the agricultural entities of the economy by the size of agricultural land by November 1,2020

\begin{tabular}{|c|c|c|c|c|}
\hline \multirow[b]{2}{*}{ Indicator } & \multicolumn{2}{|c|}{ Number of enterprises } & \multicolumn{2}{|c|}{ Agricultural land area } \\
\hline & units & $\begin{array}{c}\% \text { of total } \\
\text { amount }\end{array}$ & ths, ha & $\begin{array}{c}\% \text { of total agricultura } \\
\text { land area }\end{array}$ \\
\hline $\begin{array}{l}\text { Business owned the } \\
\text { agricultural land }\end{array}$ & 36277 & 76,3 & 20252,4 & 100,0 \\
\hline \multicolumn{5}{|l|}{ including area, ha } \\
\hline up to 5,00 & 1975 & 4,2 & 6,4 & 0,0 \\
\hline $5,01-10,00$ & 1877 & 3,9 & 14,7 & 0,1 \\
\hline $10,01-20,00$ & 3061 & 6,4 & 47,7 & 0,2 \\
\hline $20,01-50,00$ & 9395 & 19,7 & 353,3 & 1,7 \\
\hline $50,01-100,00$ & 4626 & 9,7 & 333,0 & 1,6 \\
\hline $100,01-500,00$ & 7889 & 16,6 & 1928,1 & 9,5 \\
\hline $500,01-1000,00$ & 2716 & 5,7 & 1957,9 & 9,7 \\
\hline $1000,01-2000,00$ & 2409 & 5,1 & 3458,9 & 17,1 \\
\hline $2000,01-3000,00$ & 1030 & 2,2 & 2500,3 & 12,4 \\
\hline $3000,01-4000,00$ & 473 & 1,0 & 1629,9 & 8,1 \\
\hline $4000,01-5000,00$ & 247 & 0,5 & 1099,2 & 5,4 \\
\hline $5000,01-7000,00$ & 263 & 0,6 & 1535,9 & 7,6 \\
\hline $7000,01-10000,00$ & 132 & 0,3 & 1107,0 & 5,5 \\
\hline more than 10000,00 & 184 & 0,4 & 4280,1 & 21,1 \\
\hline \multicolumn{5}{|c|}{ including farms } \\
\hline Total & 26691 & 83,8 & 4817,8 & 100,0 \\
\hline \multicolumn{5}{|l|}{ including area, ha } \\
\hline up to 1,00 & 74 & 0,2 & 0,1 & 0,0 \\
\hline $1,01-3,00$ & 742 & 2,3 & 1,7 & 0,0 \\
\hline $3,01-5,00$ & 985 & 3,1 & 4,2 & 0,1 \\
\hline $5,01-10,00$ & 1729 & 5,4 & 13,6 & 0,3 \\
\hline $10,01-20,00$ & 2797 & 8,8 & 43,7 & 0,9 \\
\hline $20,01-50,00$ & 8795 & 27,6 & 332,4 & 6,9 \\
\hline $50,01-100,00$ & 3947 & 12,4 & 282,5 & 5,9 \\
\hline $100,01-500,00$ & 5369 & 16,9 & 1258,3 & 26,1 \\
\hline $500,01-1000,00$ & 1262 & 4,0 & 897,7 & 18,6 \\
\hline $1000,01-2000,00$ & 690 & 2,2 & 951,3 & 19,8 \\
\hline $2000,01-3000,00$ & 171 & 0,5 & 411,1 & 8,5 \\
\hline $3000,01-4000,00$ & 65 & 0,2 & 219,2 & 4,6 \\
\hline more than 4000,00 & 65 & 0,2 & 402,0 & 8,3 \\
\hline
\end{tabular}

Single tax rates of the fourth group are introduced in (table 2). Taxation with a single tax does not affect the financial results of their activities, the rational use of land, the introduction of advanced technologies, adhering to crop rotation and specialization by an economic entity. 
Table 2. Single tax rates for agricultural manufacturers (fourth) group [10]

\begin{tabular}{|l|c|}
\hline \multicolumn{1}{|c|}{ Types of agricultural land } & Rate \\
\hline $\begin{array}{l}\text { for arable land, hayfields and pastures (except for arable land, hayfields and } \\
\text { pastures located in mountainous zones and in Polissia regions, as well as } \\
\text { agricultural land in closed soil conditions) }\end{array}$ & 0,95 \\
\hline $\begin{array}{l}\text { for arable land, hayfields and pastures located in mountainous zones and in } \\
\text { Polissia regions }\end{array}$ & 0,57 \\
\hline $\begin{array}{l}\text { for perennial plantations (except for perennial plantations located in } \\
\text { mountain zones and Polissia regions) }\end{array}$ & 0,57 \\
\hline $\begin{array}{l}\text { for perennial plantations located in mountainous areas and in Polissia } \\
\text { territories }\end{array}$ & 0,19 \\
\hline for land of water fund & 2,43 \\
\hline for agricultural lands in closed soil conditions & 6,33 \\
\hline
\end{tabular}

Another important aspect in the taxation of agricultural manufacturers with a single tax (fourth) group is the share of agricultural products they produce for the previous tax (reporting) year equal to or exceeding $75 \%$.

In recent years, the taxation of agricultural manufacturers has changed much. In particular, since 2015, the entities of agricultural production in the export of grain and oilseeds have been deprived of funds in the form of value added tax refunds for these operations. In addition, the tax rate for the renting agricultural land and nonagricultural land was increased by $25 \%$ by $10 \%$. Since 2016 , measures to accumulate VAT have significantly decreased, which negatively affected the level of state support for the agricultural sector, which in 2014 amounted to UAH 24.4 billion. The changes mentioned above to the current tax legislation of the agrarian sector make it impossible to increase the profitability of farmers and their costeffectiveness. Since 2015, the flat agricultural tax has been cancelled, and a single tax (fourth) group has been introduced. A methodological approach of the introduced single tax (fourth) group instead of the fixed agricultural tax has not changed except that the base and single tax rates have been increased.

Such innovations in the taxation system for business entities in the agricultural sector of the economy do not contribute to their development, especially in the sphere of lifestock production, which their activity results are shown in (table 3). In order improve taxation and tax incentives for farmers, it becomes necessary to clarify the criteria for classifying economic entities in the industry as agricultural producers. Unreasonably, economic entities that process agricultural products are not included in the Tax. Considering that fact, in recent years, the number of imported agricultural products, including livestock, has been growing.

The data in the table show that if in 2000 the import of meat and meat products accounted for only $2.3 \%$ of the total amount of manufactured products, then already in 2018-2020 12.1, 10.5 and $9.3 \%$, correspondingly. A similar trend prevails for dairy products; its importation in 2000 amounted to $0.45 \%$ of the total volume of manufactured products and for 2019-2020. 3.49 or $7.46 \%$, correspondingly. 
Table 3. The level of profitability of agricultural production in agricultural enterprises, \% [11]

\begin{tabular}{|c|c|c|c|c|c|c|c|c|}
\hline Year & Crop & $\begin{array}{c}\text { Sunflower } \\
\text { seed }\end{array}$ & $\begin{array}{c}\text { Sugar } \\
\text { beet }\end{array}$ & $\begin{array}{c}\text { Bovine } \\
\text { meat }\end{array}$ & Pork & Poultry & $\begin{array}{c}\text { Dairy } \\
\text { products }\end{array}$ & Eggs \\
\hline 2010 & 13,9 & 64,7 & 16,7 & $-35,9$ & $-7,8$ & $-4,4$ & 17,9 & 18,6 \\
\hline 2011 & 26,1 & 57,0 & 36,5 & $-24,8$ & $-3,7$ & $-16,8$ & 18,5 & 38,8 \\
\hline 2012 & 15,2 & 45,8 & 15,7 & $-29,5$ & 2,0 & $-7,2$ & 2,3 & 52,6 \\
\hline 2013 & 1,5 & 28,5 & 2,7 & $-43,3$ & 0,2 & $-10,0$ & 13,6 & 47,6 \\
\hline 2014 & 25,8 & 36,5 & 17,9 & $-35,9$ & 5,6 & $-15,4$ & 11,0 & 58,8 \\
\hline 2015 & 43,1 & 80,5 & 28,2 & $-17,9$ & 12,7 & $-6,1$ & 12,6 & 60,9 \\
\hline 2016 & 37,8 & 63,0 & 24,3 & $-24,8$ & $-4,5$ & 5,0 & 18,2 & 0,5 \\
\hline 2017 & 25,0 & 41,3 & 12,4 & 3,4 & 3,5 & 7,0 & 26,9 & $-9,0$ \\
\hline 2018 & 24,7 & 32,5 & $-11,4$ & $-17,7$ & 6,9 & 5,7 & 16,1 & 5,4 \\
\hline 2019 & 11,8 & 23,5 & $-15,4$ & $-27,1$ & 4,7 & $-3,7$ & 20,6 & $-23,5$ \\
\hline 2020 & 20,0 & 39,4 & $-13,5$ & $-24,2$ & 2,6 & $-0,2$ & 20,1 & $-19,2$ \\
\hline
\end{tabular}

According to the results of the research "Pro Agro Group" with reference to the data of UCAB in 10 months of 2021, 88.6 thousand tons of dairy products were imported, which is $18 \%$ more than in the same period last year. In terms of money, imports increased by $22 \%$ and amounted to $\$ 297$ million.

Table 4. Exportation and importation of livestock products in Ukraine, by years, in thousand tons

\begin{tabular}{|l|c|c|c|c|c|c|c|c|}
\hline \multicolumn{1}{|c|}{ Type of product } & 2000 & 2005 & 2010 & 2015 & 2017 & 2018 & 2019 & 2020 \\
\hline $\begin{array}{l}\text { Meat and meat products } \\
\text {-production }\end{array}$ & 1663 & 1597 & 2059 & 2323 & 2318 & 2355 & 2492 & 2478 \\
\hline -exportation & 163 & 82 & 48 & 245 & 351 & 399 & 487 & 473 \\
\hline in \% to the output & 9,8 & 5,1 & 2,3 & 10,5 & 15,1 & 16,9 & 19,5 & 19,1 \\
\hline -importation & 38 & 325 & 378 & 158 & 233 & 283 & 261 & 230 \\
\hline in \% to the output & 2,3 & 20,3 & 18,4 & 6,8 & 9,9 & 12,1 & 10,5 & 9,3 \\
\hline $\begin{array}{l}\text { Dairy products } \\
\text {-production }\end{array}$ & 12658 & 13714 & 11249 & 10615 & 10281 & 10064 & 9663 & 9264 \\
\hline -exportation & 1100 & 1901 & 956 & 464 & 835 & 807 & 593 & 440 \\
\hline in \% to the output & 8,7 & 13,9 & 8,5 & 4,4 & 8,1 & 8,0 & 6,1 & 4,7 \\
\hline -importation & 50 & 112 & 273 & 78 & 132 & 180 & 337 & 691 \\
\hline in \% to the output & 0,45 & 0,82 & 2,43 & 0,73 & 1,28 & 1,79 & 3,49 & 7,46 \\
\hline
\end{tabular}

The increase in supplies took place for dairy products, except for butter. The growth in milk and dairy products importation to Ukraine is primarily due to the rapid decline in the number of cattle and the increase in national prices for raw materials. According to the Department of State Statistics, the tendency in decrease 
in animals is most took place in households, where by October 1, a decrease of $-7 \%$ occurred over a year" [12].

Taking this into account, there will be an increasing in the number of processing enterprises of agricultural products, the problem solution of marketing agricultural products and at the same time improving the functioning of agricultural producers who are already on a simplified taxation system. Increasing use of benefits for enterprises of agricultural products manufacturing, with the simultaneous introduction of modifying the Tax Code of Ukraine will contribute to an increase in the number of economic entities in the industry, which can be classified as agricultural, which prospectively will be able to use a special tax regime, as well as benefits in their taxation.

Previous studies have shown that agricultural producers mainly are engaged in the cultivation of agricultural crops that gives the chance to get high profits without unnecessary problems with searching marketing strategies. The livestock industry has traditionally been unprofitable due to increasing in energy prices, animal feed, veterinary drugs, etc.

In the current version, the single tax for farmers (fourth) group according to the study of O. M. Mohylnyi "... the tax does not take into consideration production expenses and the level of profitability of agricultural producers; tax rates are calculated on an imperfect basis of monetary valuation of land due to the underdevelopment of the land market; not all taxes included in it depend on the size of agricultural land. However, fairness suffers as a result of this " [13, p. 125-126].

As a result of the differentiation of taxation at the intra-industry level in agriculture, it is impossible to establish a single rate for all types of agricultural land by revising the rates of the single tax (fourth group), since the application of a single rate for this tax cannot be attributed to the same type of industry. Considering this, the establishment of a single rate for this tax is premature. Differentiation of tax overload in agriculture according to research by V. P. Zhmudynskyi is evidenced not only by the use of different rates depending on the type of agricultural land, but also by the creation of prerequisites for the effective functioning of taxable mechanisms [14].

In order to optimize the pricing policy, it is necessary to change the mechanism of taxation of farmers with value added tax for business entities that are on a simplified taxation system. Taking this into account, it is necessary to restore the mechanism of taxation with value added tax, in which the entire amount of the tax liability remained at the disposal of the agricultural enterprise and was directed to expanded reproduction. The applying of such a mechanism for imposing value added tax on farmers will not only allow them to function successfully on the basis of expanded reproduction, but also reduce prices for agricultural products to end consumers. The use of such a mechanism for imposing value added tax on farmers will not only allow them to function successfully on the basis of expanded reproduction, but also reduce prices for agricultural products to final consumers. The applying of such a taxation regime will allow to concentrate the majority of agricultural producers and processors of agricultural products in the area of the 
preferential tax regime application. Considering the biased specialization of agricultural production, the single tax rates should be introduced depending on the profile of the economic entity (table 5).

Table 5. Proposed rates of the single tax (fourth group) for agricultural enterprises and enterprises for processing agricultural products, \%

\begin{tabular}{|l|c|}
\hline \multicolumn{1}{|c|}{ Business entity profile } & $\begin{array}{c}\text { Tax rate, \% of the monetary } \\
\text { value of the land }\end{array}$ \\
\hline horticulture & 3 \\
\hline Poultry farming & 6 \\
\hline Other branches of livestock farming & 1 \\
\hline Processing of agricultural products & 6 \\
\hline
\end{tabular}

Provided that an economic entity receives income from other activities, the tax should be calculated for each profile separately, using the tax rate.

Conclusions. Taking into account the previous information, it is necessary to address the weaknesses in the single tax withholding mechanism (fourth group) by creating the prerequisites for its application by both agricultural producers and agricultural processing enterprises, taking into account the level of specialization of each individual economic entity. It is necessary to differentiate the level of the tax burden by establishing evidence-based tax rates depending on the specialization of the enterprise. Clarify the criteria for assigning an economic entity to the list of agricultural producers. Verify the mechanism for taxing value added tax for agricultural producers.

\section{Література}

1. Антіпова О. Лист: Державна фіскальна служба України від 13.03.2019 № 11803/6/99-99-12-02-03-15.

URL: https://zakononline.com.ua/documents/show/89266_89266

2. Бечко П. К., Власюк С. А., Бондаренко Н. В., Нагорна Ю. І. Податкове стимулювання сільськогосподарських товаровиробників як метод державного регулювання галузі. Proc. of IV International Scientific and Practical Conference «Dynamics of the development of world science». Vancouver, Canada, 18-20 December 2019. P. 342-353

3. Бичков В. Документальні перевірки. Вісник. Офіційно про податки. URL: http://www.visnuk.com.ua/uk/publication/100008647-dokumentalni-perevirki2

4. Брехов С. Концептуалізація системи управління податковими ризиками : стратегічні цілі та напрями реформування Державної податкової служби України. Вісник соиіально-економічних досліджень. 2019. Вип. 2-3. С. 106-117.

5. Вилкова Е., Романовский М. Налоговое планирование. СПб: Питер. 2004. 93 c. 
6. Пригоцький В. А. Щодо природи відносин податкового органу i платника під час адміністративного апеляційного оскарження. Юриспруденція. Теорія і практика. 2010. № 10 (72). С. 32-36.

7. Проскура К. П. Особливості адміністрування податків в Україні. Економічний часопис-XXI. 2012. № 3-4. С. 53-55. URL: http://dspace.nbuv.gov.ua/handle/123456789/48214

8. Сидоренко Р. В. Оподаткування діяльності сільськогосподарських підприємств: сучасний стан та перспективи. Причорноморські економічні студіï. 2016. Випуск 12(2.) С. 173-176

9. Ковтун В. А. Організаційно-економічні аспекти діяльності аграрних підприємств. Розвиток економіки Украӥни в контексті активізаиії підприємницької діяльності. За редакцією Н. С. Танклевської. Херсон. С. 15-22.

10. Податковий кодекс України. URL: https://zakon.rada.gov.ua/laws/show/2755-17\#Text.

11. Статистичний збірник "Сільське господарство України" Державна служба статистики України. 2021.426 с.

12. У січні-жовтні 2021 року імпорт молочної продукції зріс на $18 \%$. URL: https://proagro.com.ua/tvarynnyctvo/molokovyrobnycztvo/u-sichni-zhovtni-2021roku-import-molochnoyi-produkcziyi-zris-na-18.html

13. Могильний О. М. Регулювання аграрної сфери: монографія. Ужгород: IBA, 2005. $400 \mathrm{c}$.

14. Жмудінський В. П. Щорічне підтвердження статусу платника єдиного податку четвертої групи: окремі проблемні питання. Матеріали міжнар. наук.практ. конф. "Науковий потенціал та перспективи розвитку юридичної науки". Запоріжжя: Юридичний факультет Запорізького національного університету, 2019. C. 39-42.

\section{References}

1. Antipova, O. (2019). Letter: State Fiscal Service of Ukraine.№ 11803/6 / 9999-12-02-03-15. URL: https://zakononline.com.ua/documents/show/89266_89266

2. Bechko, P. K, Vlasiuk, S. A, Bondarenko, N. V, Nagorna, Y. I. (2019). Tax incentives for agricultural producers as a method of state regulation of the industry. Proc. of IV International Scientific and Practical Conference "Dynamics of the development of world science" Vancouver, Canada, December 18-19. Vancouver, Canada. P. 342-353

3. Bychkov, V. Documentary inspections. Visnyk. Officially about taxes. URL: http://www.visnuk.com.ua/en/publication/100008647-dokumentalni-perevirki-

5. Vilkova, E., Romanovsky, M. (2004). Tax planning. St. Peter., 2004. 93 p.

6. Prigotskyi, V. A. (2010). Regarding the nature of the relationship between the tax authority and the payer during the administrative appeal. Jurisprudence. Theory and practice, 2010, no. 10 (72), pp. 32-36.

8. Sydorenko, R. V.(2016). Taxation of agricultural enterprises: current status and prospects. Black Sea Economic Studies, 2016, issue 12(2), pp. 173-176 
9. Kovtun, V. A. Organizational and economic aspects of agricultural enterprises. Development of the economy of Ukraine in the context of activation of entrepreneurial activity. Edited by N. S. Tanklevska. Kherson. P. 15-22.9.

10. Tax Code of Ukraine. URL: https://zakon.rada.gov.ua/laws/show/275517\#Text.10.

11. Statistical collection "Agriculture of Ukraine" State Statistics Service of Ukraine. (2021) .p. 426

12. In January-October 2021 imports of dairy products increased by $18 \%$. URL: https://proagro.com.ua/tvarynnyctvo/molokovyrobnycztvo/u-sichni-zhovtni-2021roku-import-molochnoyi-produkcziyi-zris-na-18.html

13. Mogilnyi, O. M. (2005). Regulation of the agricultural sector: a monograph. Uzhhorod: IVA, 2005. $400 \mathrm{p}$.

14. Zhmudinskyi, V. P. (2019). Annual confirmation of the status of the single tax payer of the fourth group: some problematic issues. Materials of international scientific-practical conf. "Scientific potential and prospects of legal science development" Zaporizhzhia, March 22-23. Faculty of Law of Zaporizhzhia National University. P. 39-42.

\section{Аннотация}

\section{Непочатенко Е. А., Бечко П. К., Власюк С. А., Пономаренко О. В., Нагорная Ю. И. \\ Перспективы развития механизмов налогового стимулирования субъектов хозяйства аграрного сектора экономики}

Выяснено, что в современных условиях хозяйствования аграрная отрасль находится перед системным вызовом, первоочередной задачей, которого, является решение проблем качественно новой модели ее развития $c$ применением государственной финансовой поддержски. Основным инструментом поддержки выступает налоговое стимулирование на основе дифференцированного подхода в зависимости от конкретных сумм прямой государственной финансовой поддержски, получаемой каждый хозяйствующим субъектом. Развитие механизмов налогового стимулирования находится в поле зрения как научных работников, так и практиков, исследующих проблемь налогообложения аграриев. Однако решения этой проблемы для аграриев в масштабе государства в современных условиях еще не в полной мере исследованы, требуют дальнейшего изучения, применяя как зарубежный, так и отечественный опыт с иелью его адаптации в отечественную налоговую систему.

Для обоснования теоретических аспектов перспектив развития механизмов налогового стимулирования использованы передовые методологические приемы, наработанные как мировой, так и отечественной практикой налоговой системы и научные разработки зарубежных $и$ отечественных ученых по проблемам развития механизмов налогового стимулирования субъектов хозяйствования аграрного сектора экономики. В ходе исследования выяснено, что для совершенствования налогообложения $u$ налогового стимулирования аграриев возникает необходимость уточнения критериев отнесения хозяйствующих субъектов отрасли $к$ 
сельскохозяйственным товаропроизводителям. Необоснованно в Налоговый кодекс не внесены хозяйствуюшие субъекты, которые перерабатывают сельскохозяйственную продукиию.

Учитывая это, в последние годы растет количество импортированной сельскохозяйственной продукичи $и$, в том числе и жнивотноводческой. Сформирован, систематизирован и предложен авторский подход $к$ перспективам развития механизмов налогового стимулирования субъектов хозяйствования аграрного сектора экономики. Так, на законодательном уровне следует ввести изменения в Налоговый кодекс Украины о налогообложении аграриев единым налогом (четвертая группа), в зависимости от их специиализачии, предоставив преференции сельскохозяйственным товаропроизводителям по производству животноводческой продукции и ее переработке.

Ключевые слова: единый налог (четвертая) группа, спецзиализациия производства, Налоговый кодекс Украины, уровень рентабельности, минимизация налоговых обязательств, упрощенная система налогообложения.

\section{Annotation}

\section{Nepochatenko O. O., Bechko P. K., Vlasiuk S. A., Ponomarenko O. V.,} Nahorna Y.I.

Development prospects of incentive taxation mechanisms of business entities in agricultural sector of the economy

In the contemporary world, the agricultural industry faces a system call, which priority is to resolve the problem of a new high-quality model of development with the use of state financial support, which main tool is tax incentives based on a differentiated approach depending on the specific amounts of direct state financial support that is received by each business entity. The contemporary nature of development mechanism for incentive taxation of economic entities in agricultural sector of the economy is under constant review of both theorists and practitioners who study the taxation problems of farmers. However, solution to this issue for national farmers in current situation has not yet been completely researched; they require further study, using both foreign and native experience in order to implement it in national tax system.

To justify the theoretical aspects of the development prospects of tax incentive mechanisms, best practices have been used, developed by both international and native practice of the tax system and scientific progress of foreign and native scientists who researched the development of tax incentive mechanisms for business entities in agricultural sector of the economy. It was proved that in order to improve taxation and tax incentives for farmers, it becomes necessary to clarify the criteria for classifying business entities in the industry as agricultural manufacturers. Unreasonably, economic entities that process agricultural products are not included in the Tax Code.

Considering this, within years, the number of imported agricultural products, including livestock products, has been increasing. The result was a new author's approach to dealing with the development prospects of tax incentives mechanism for business entities in the agricultural sector of the economy. So, at the legislative level, it is necessary to make amendments to the Tax Code of Ukraine on taxation of agrarians with a single tax (fourth group), depending on their specialization, by 
providing preferences to agricultural producers for the production of livestock products and their processing.

Key words: single (flat) tax (fourth) group, production specialization, Tax Code of Ukraine, profitability, minimization of tax liabilities, simplified taxation.

\section{ЛОГІСТИЧНІ ПІДХОДИ ДО ОРГАНІЗАЩІЇ ЗБУТОВОЇ ДІЯЛЬНОСТІ ПІДПРИЕМСТВА}

Т. В. ЧЕРНИЧКО, доктор економічних наук

Мукачівський державний університет

В. І. РИБЧАК, кандидат економічних наук

Уманський національний університет садівництва

С. Ф. ЧЕРНИЧКО, кандидат економічних наук

Ужгородський торговельно-економічний інститут КНТЕУ

У статті окреслено особливості логістичних підходів до збутової діяльності підприємства з позииії організачії потових процесів. Використання потокової організації збутової діяльності підприємства трунтується на формуванні логістичного ланцюгу та єдиної інтегрованої системи потоків сукупності поєднаних за певною ознакою об'єктів, щуо рухається в просторі та часі та адаптовані до кількісних та якісних перетворень відповідно до дії на них суб'єкта управління логістичною системою. Обтрунтовано принципи та критерії оцінювання інноваційності потокової організації збутової діяльності підприємства.

Ключові слова: збут, збутова діяльність, підприємство, товарні потоки, збутова логістика.

Конкурентні позиції підприємств на сучасному ринку залежать від їх спроможності забезпечити доступність товарів для споживачів та рівня якості ïх збутової діяльності. При розробці стратегій розвитку підприємств, управлінський персонал все частіше згадує про використання логістичних підходів, як чинника впливу на доходи підприємств.

Аналіз останніх досліджень і публікацій. В сучасній економічній літературі чітко простежуються три основні підходи щодо побудови логістичних схем організації збутової діяльності підприємств.

Перший підхід - функціональний - грунтується на представленні логістичної збутової діяльності з позицій двох груп основних функцій: функцій, що пов'язані з організацією руху товарно-матеріальних цінностей до споживача та підтримкою їх у належному стані (фізичний розподіл продукції, вантажнорозвантажувальні роботи, організація складського господарства, збереження, 